\title{
TUTORIAL GRAMMARLY PREMIUM
}

\section{AUTHORS}

Muh. Barid Nizarudin Wajdi

M. Adhi Prasnowo

Robbi Rahim

\section{AFFILIATION}

- $\quad$ STAI Miftahul Ula Nganjuk

- Universitas Hasyim Maarif Latif Sidoarjo

- Institut Teknologi Medan

\section{DEFINITIONS}

Grammarly merupakan tool khusus yang digunakan untuk membantu melakukan pemeriksaan grammatical errors, vocabulary enhancement suggestions, detects plagiarism, and citation suggestions.

\section{FACILITIES OF PREMIUM}

1. Critical grammar and spelling checks

2. Advanced checks for punctuation, grammar, context, and sentence structure

3. Vocabulary enhancement suggestions

4. Genre-specific writing style checks

5. Plagiarism detector that checks more than 8 billion web pages

6. Unlimited Check Grammar, Plagiarism (Only for English)

7. Run on Windows (Desktop \& Web), MAC (Web), Linux (Web)

\section{EMAIL}

- baridnizar84@gmail.com

- prasnowoadhi@dosen.umaha.ac.id

- robbirahim@ko2pi.org 


\section{TUTORIAL GRAMMARLY PREMIUM}

\section{Tutorial Grammarly Versi Premium}

1. Akun premium akan didapatkan setelah berlangganan pertahun. Nanti akan ada aktivasi by email. Silahkan klik linknya

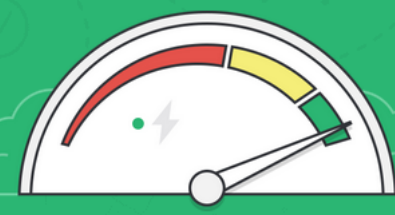

\section{Take Your Writing to the Max}

Welcome to Grammarly! The good people at Indonesian Publications

Collaboration Community have partnered with us to offer their members

a premium account. All you have to do is complete your registration and

you'll get access to every single feature listed below. We hope this is the

beginning of a beautifully polished friendship.

2. Silahkan ikuti langkah berikutnya untuk mendapatkan login premium. Kemudian setelah aktivasi, akan menuju grammarly premium (ada tanda premiumnya) 


\section{TUTORIAL GRAMMARLY PREMIUM}

MUH. BARID NIZARUDIN WAJDI, ADHI PRASNOWO, ROBBI RAHIM

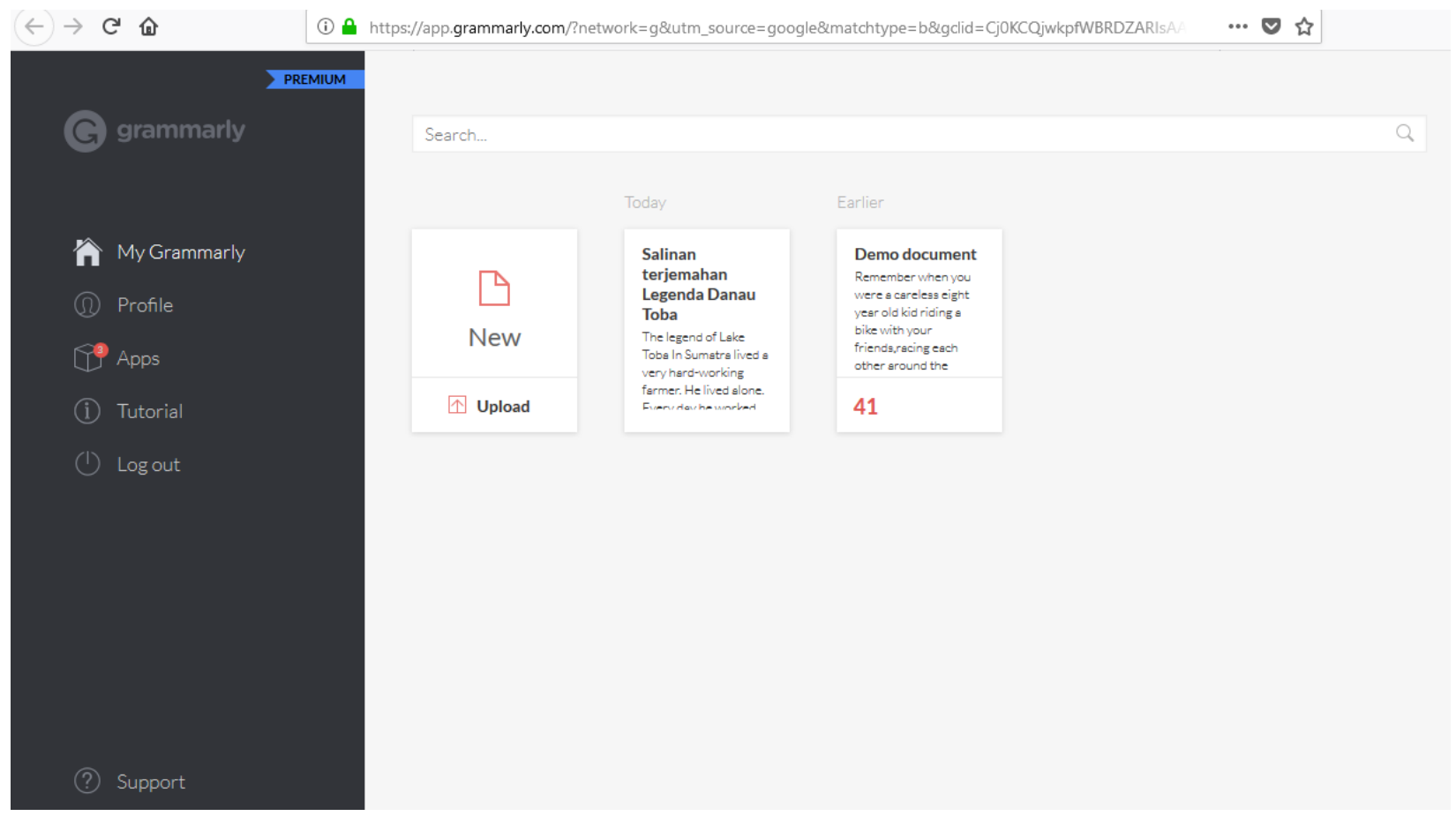

3. Setelah itu... klik new (UPLOAD)

4. Ada beberapa fitur yang di dapat pada akun premium (non-trial) 


\section{TUTORIAL GRAMMARLY PREMIUM}

MUH. BARID NIZARUDIN WAJDI, ADHI PRASNOWO, ROBBI RAHIM

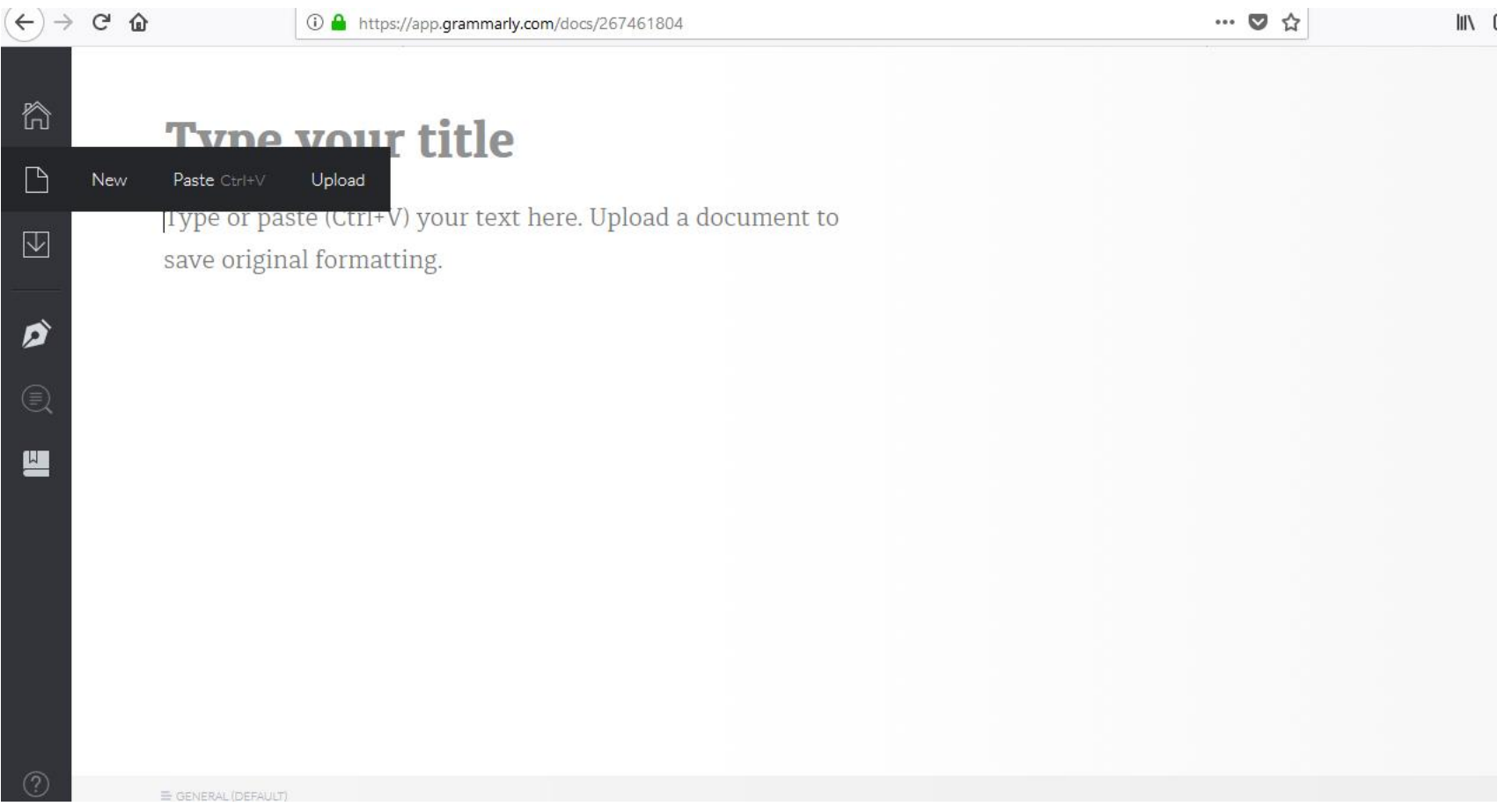

New : upload text atau paste text yang mau di perbaiki (english) Paste : salin

Upload : silahkan upload filenya (word, doc, pdf) 


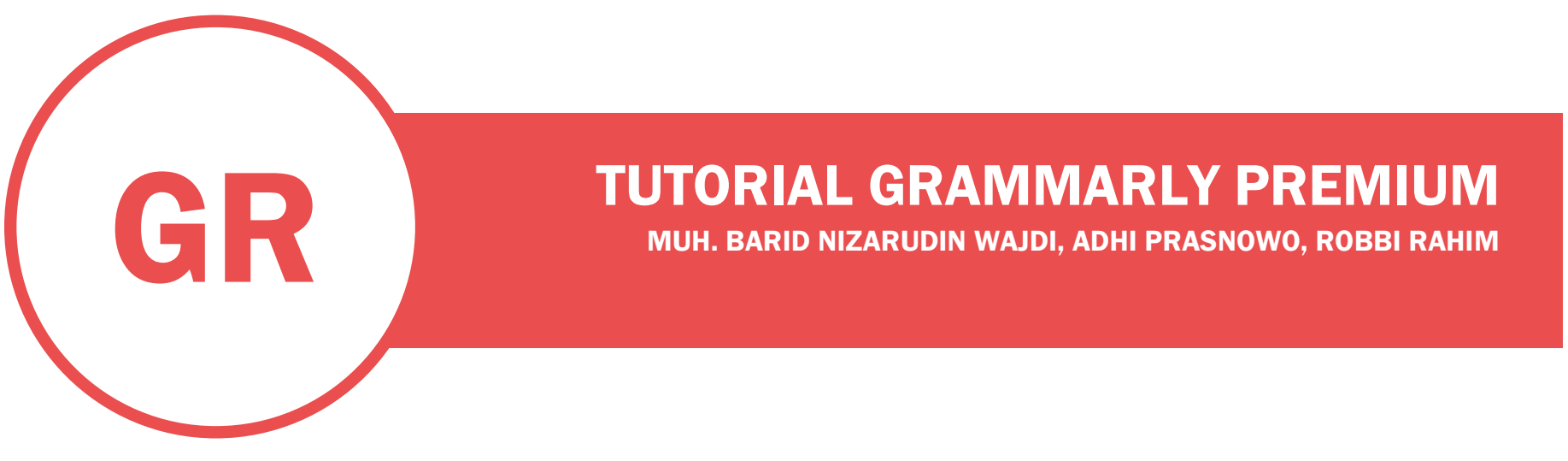

$\leftarrow \rightarrow C$ O

(i) https://app.grammarly.com/docs/290590941

...句

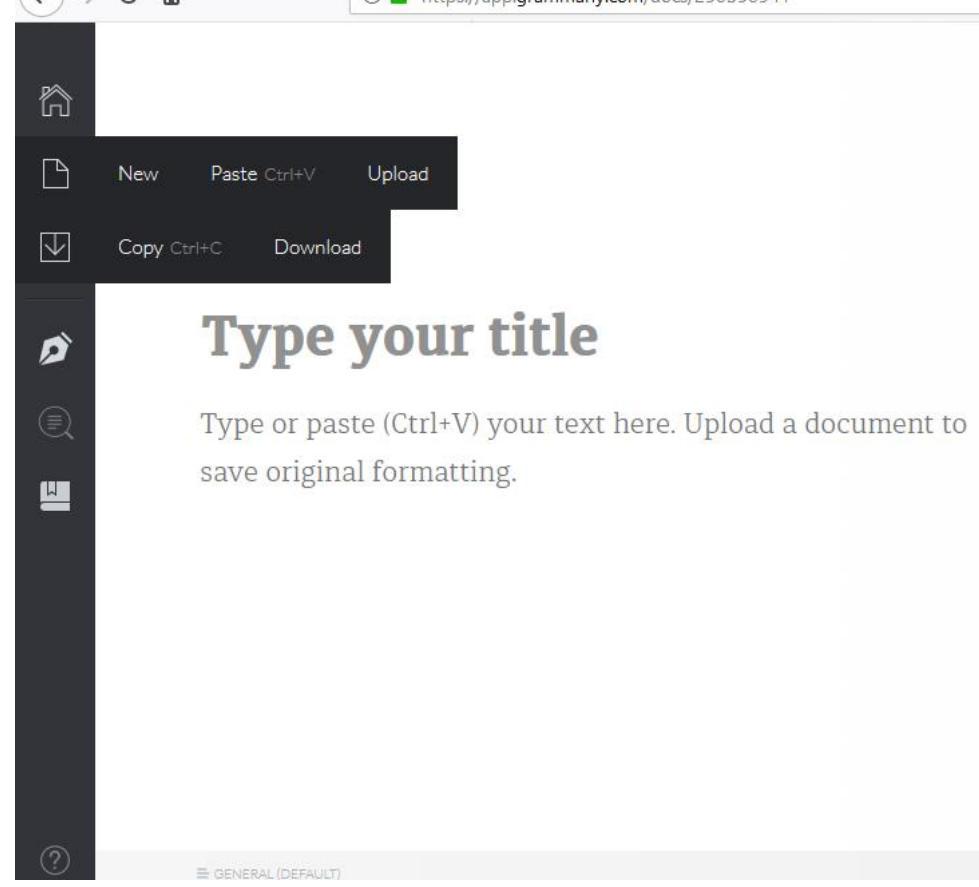

Copy : mencopy hasil perbaikan Download : mendownload hasil perbaikan 


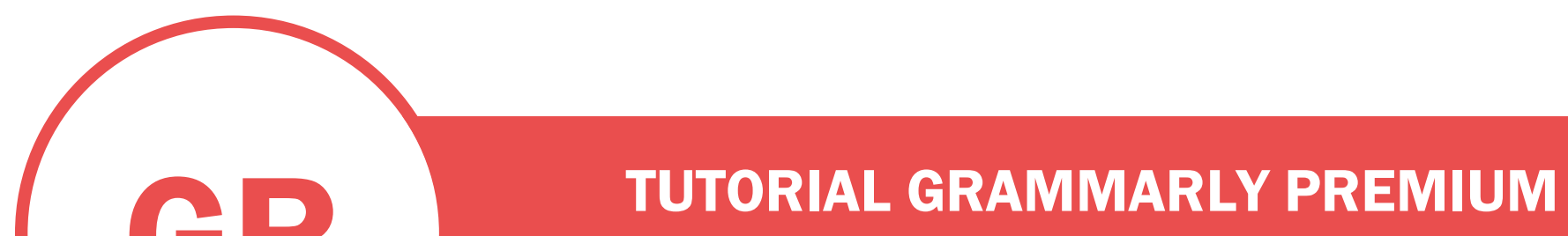

MUH. BARID NIZARUDIN WAJDI, ADHI PRASNOWO, ROBBI RAHIM

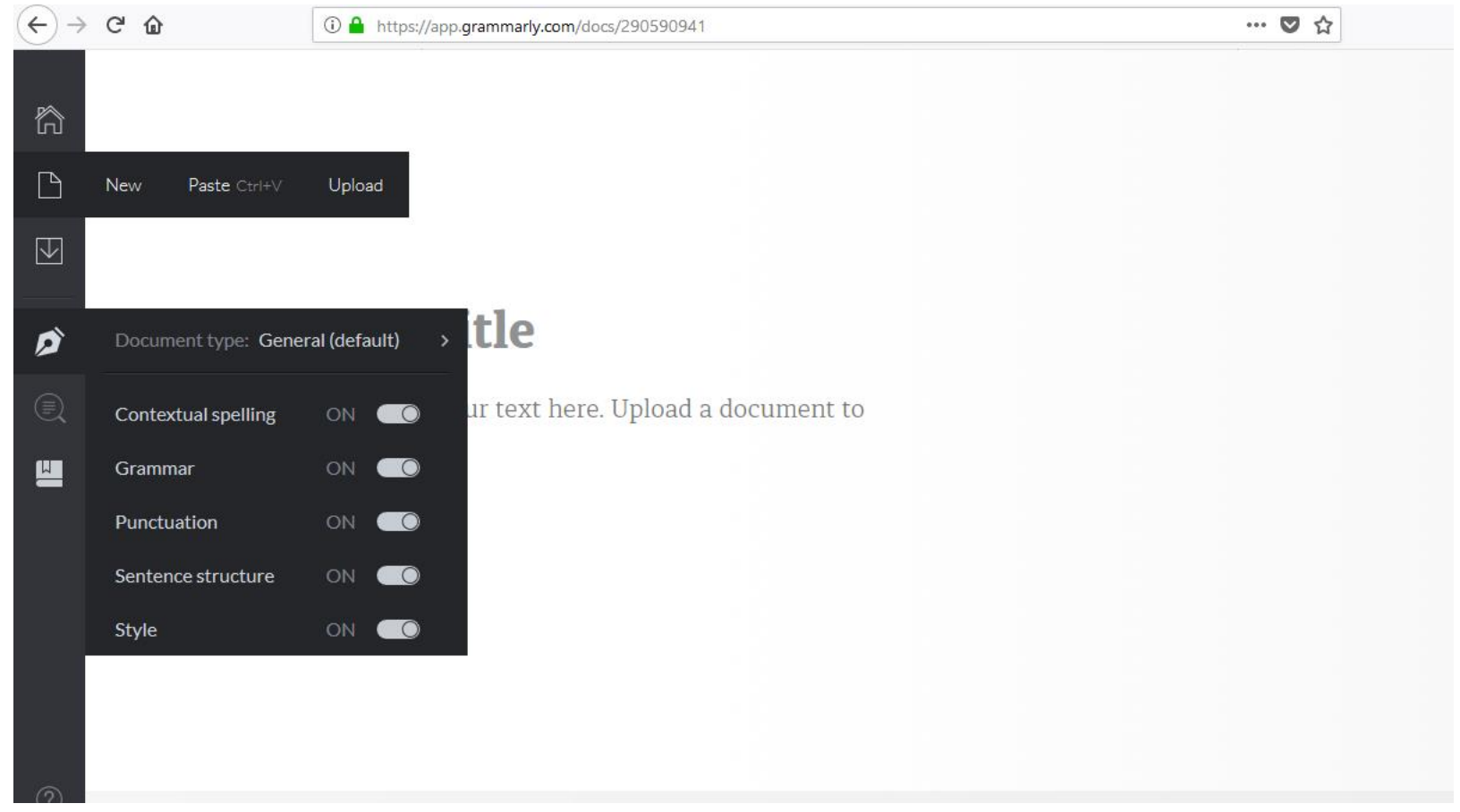

\section{Pengaturan Premium}

On kan semua 


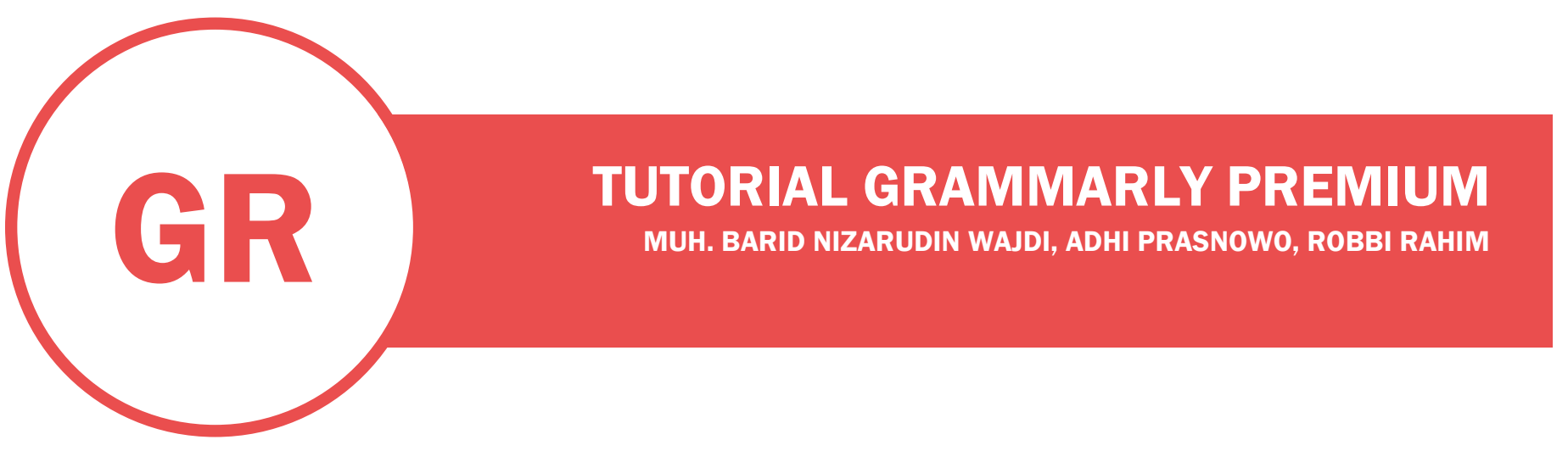

$(\leftarrow) \rightarrow$ C 田 $\quad$ (i) O https://app.grammarly.com/docs/290590941 $\quad$...

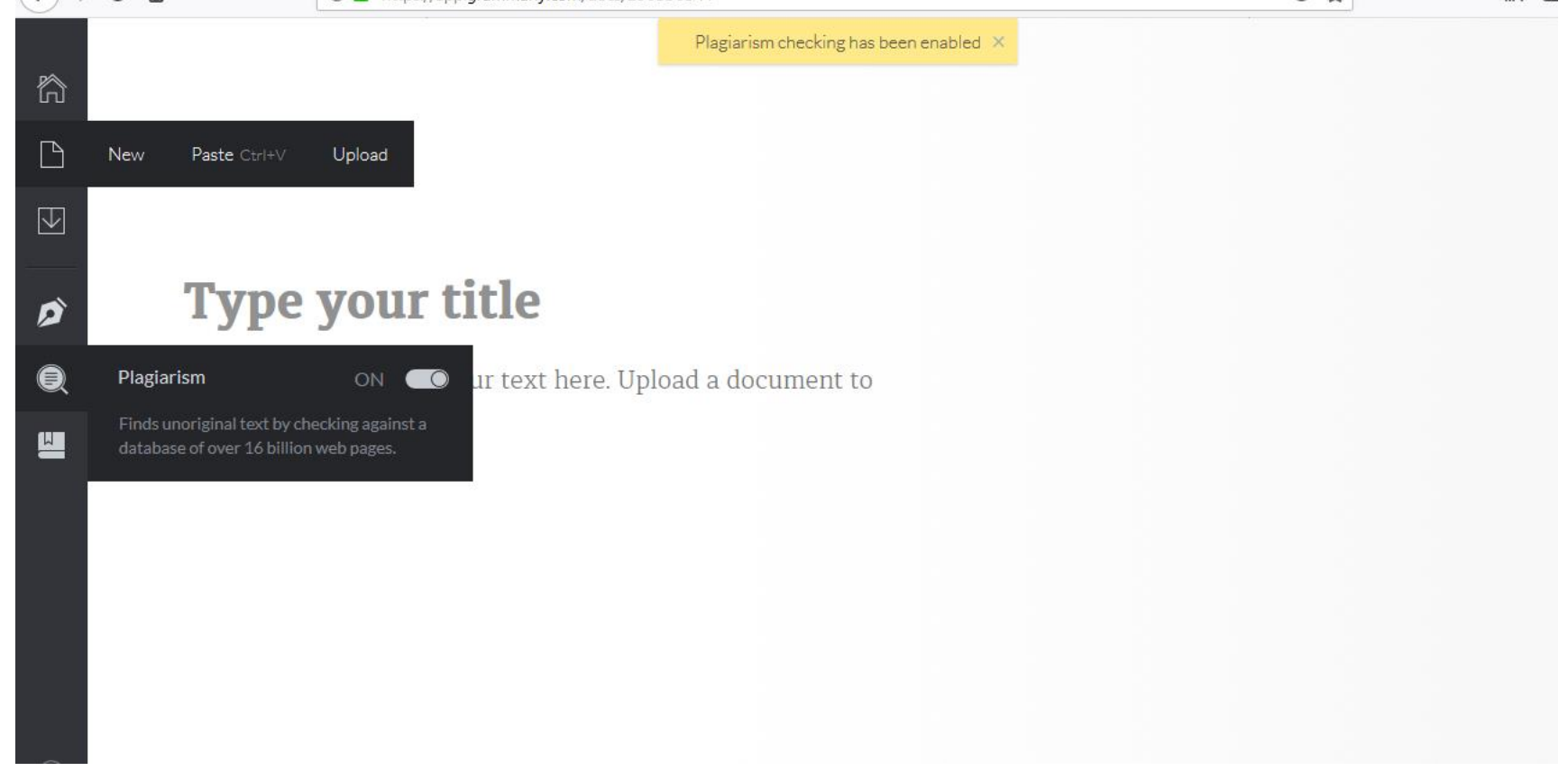

Pengaturan Plagiarisme On kan

5. Berikut contoh artikel yang sudah di upload 


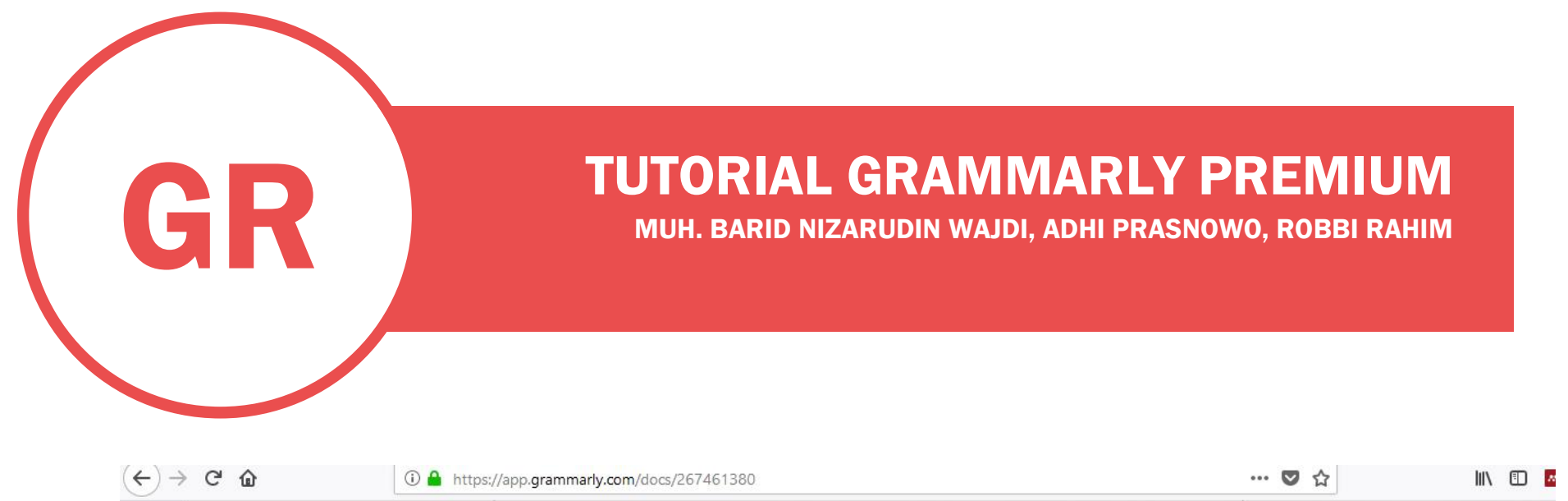

\section{Demo document}

Remember when you were a careless eight year old kid riding a bike with your friends,racing each other around the neighborhood? Remember that feeling of absolute freedom as you felt the wind in your hair and the smile it put on your face? I never thought I would feel that way as a grown up,until my friends presented me a red brand-new bike. At first,I was a bit skeptical about the total idea of commuting by bike. One morning a couple of days later,I changed completely my mind. I was stuck at a traffic jam and saw in my rear mirror a man in a suit riding a classy bike with his laptop case in one hand and a handlebar in the other. I figured out it would take him about 15 minutes to get to the office while I was still sitting in my car and waiting for the cars in line ahead to move,even if just for a inch. I was always very afraid of being late for my business meetings.

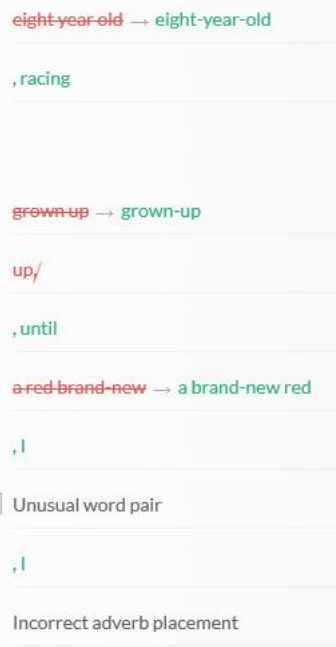

45 CRITICAL ISSUES 17 ADVANCED ISSUES

Tanda merah (garis bawah) adalah file yang perlu diperbaiki) merah kanan adalah fiel yang perlu diperbaiki. Tinggal klik hijaunya, maka akan diperbaiki oleh softwarenya.

Ada catatan dibawah tentang jumlah critical issue dan advance issue.. semakin sedikit critical issue dan advanced issue, maka akan semakin baik. Berikut disertakan score nya 


\section{TUTORIAL GRAMMARLY PREMIUM}

\section{MUH. BARID NIZARUDIN WAJDI, ADHI PRASNOWO, ROBBI RAHIM}

\section{Demo document}

Remember when you were a careless eight year old kid riding a

bike with your friends,racing each other around the

neighborhood? Remember that feeling of absolute freedom as

you felt the wind in your hair and the smile it put on your face?

I never thought I would feel that way as a grown up,until my friends presented me a red brand-new bike. At first,I was a bit skeptical about the total idea of commuting by bike. One morning a couple of days later,I changed completely my mind. I was stuck at a traffic jam and saw in my rear mirror a man in a suit riding a classy bike with his laptop case in one hand and a hnndlnhnr in thenthnr I firurnd nut it rarnuld tolon him nhout 15
Unoriginal text: 47 words

packetstormsecurity.com/files/146263/GS20180206172529.txt

A part of your paper is matching some text from the web. Please make sure that this text is properly referenced.

Consider using the following citation data to create a reference in MLA, APA or Chicago styles:

URL:

https://packetstormsecurity.com/files/146263/GS201802061.

Website Title:

Grammarly Auth Token Exposure $\approx$ Packet Storm

Date Accessed:

April 05, 2018

Ketika diklik artikel yang diupload, akan muncul blok warna kuning, itu menunjukkan link yang dianggap plagiarisme.

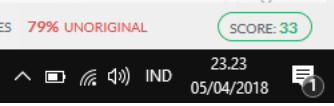

Dibawahnya akan ditunjukkan juga similiritynya.

6. Apabila telah selesai, bisa di download hasil perbaikannya 


\section{TUTORIAL GRAMMARLY PREMIUM}

Demo docum

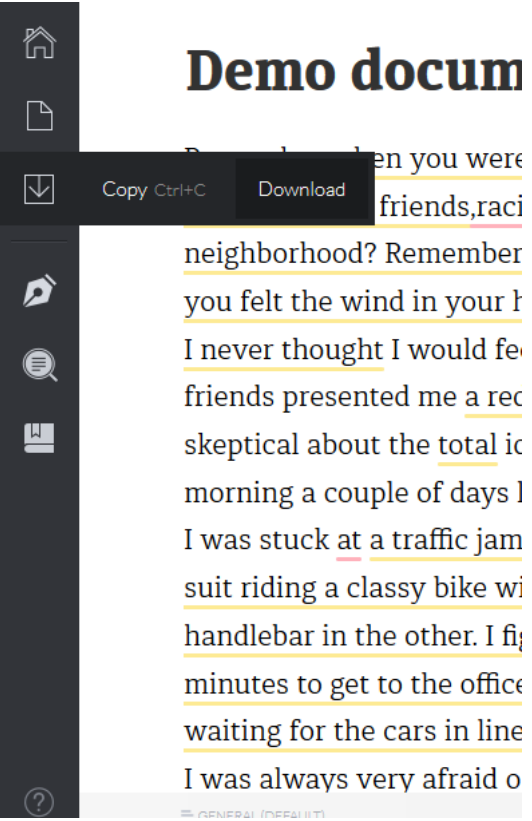

7. Untuk melihat hasil secara keseluruhan, baik, checking grammar, critical issue dan advance issue, silahkan klik score (bawah kanan)

Incorrect adverb placement

45 CRITICAL ISSUES 17 ADVANCED ISSUES $79 \%$ UNORIGINAL SCORE: 33

8. Report akan ditunjukkan, dan bisa di download. 


\section{TUTORIAL GRAMMARLY PREMIUM}

\section{MUH. BARID NIZARUDIN WAJDI, ADHI PRASNOWO, ROBBI RAHIM}

D. https://app.grammarly.com/docs/267461380

‥v穴

dc Keep at it, Barid

You still have room for improvement. (Don't we all?) Style and

Grammar seem to be giving you trouble. Review your work

carefully.

SCORE

33

ALERTS

62

ir fri

d? R

vind

sht I

ntec

ut $\mathrm{t}]$

upl€

t a t

zlass

the

et to

le cé

ver

\section{Contextual Spelling}

Misspelled Words

Commonly Confused Words

Confused Words

Grammar

Incorrect Verb Forms

Wrong or Missing Prepositions

9. Demikian turorial ini kami sajikan. Segala kekurangan dan kekhilafan, mohon maaf yang sebesar besarnya.

10. Selamat mencoba

Quote Today

Godaan Peneliti Sekarang ada beberapa macam, harta, tahta, wanita dan Kuota (HR. Sendiri) 